\title{
The historical differential diagnosis of the disease that afflicted Aleijadinho, the famous 18th century Brazilian sculptor
}

\author{
O histórico diagnóstico diferencial da doença que afetou Aleijadinho, famoso escultor \\ brasileiro do século XVIII
}

Renato Puccioni SOHLER', Leonã Santana DE LIMA1', Vinícius Zanotti ZATTA', Claude Jacques CHAMBRIARD², Marcos Raimundo Gomes DE FREITAS ${ }^{2,3}$

\begin{abstract}
Background: The famous Brazilian Baroque sculptor named Antônio Francisco Lisboa, known as "Aleijadinho" (1738-1814), suffered from a deforming disease of the lower and upper limbs. The condition was characterized by atrophy, paresis and amputation. His face was also affected, with inflammation of the eyelids, deviation of the labial commissure, drooping of the chin and lower lip, giving him a sinister expression. Despite the disabling and chronic illness, he produced several works of great expression in the 18th and 19th centuries. Some of them were declared World Heritage Sites by United Nations Educational, Scientific and Cultural Organization (UNESCO). Objective: To discuss the historical differential diagnosis of Aleijadinho's disease through a narrative review of the literature. Methods: Scientific articles were searched in databases such as Google Scholar, Pubmed and Lilacs using the term "Aleijadinho". Subsequently, data were collected in articles and books about the possible diseases of the sculptor. Results: Since the first clinical report on the sculptor, several historians and doctors have attempted to establish a diagnosis and several hypotheses have been proposed such as: syphilis, yaws (frambesia tropica), rheumatoid arthritis, Hansen's disease (leprosy), thromboangiitis obliterans (Buerger disease), zamparina, cardina, porphyria cutanea tarda, stroke, amyloidosis, trauma and/or scurvy. Conclusions: Based on the literature, the authors conclude that the most likely diagnosis of Aleijadinho's disease is consistent with leprosy.
\end{abstract}

Keywords: Art; Diagnosis; Leprosy.

\section{RESUMO}

Antecedentes: O famoso escultor barroco brasileiro Antônio Francisco Lisboa, conhecido como "Aleijadinho", desenvolveu uma doença deformante das extremidades dos membros inferiores e superiores. O distúrbio foi caracterizado por atrofia, paresia e amputação. Seu rosto também foi afetado, com inflamação das pálpebras, desvio da comissura labial, queda do queixo e lábio inferior, dando-lhe uma expressão sinistra. Apesar da doença incapacitante e crônica, ele produziu diversas obras de grande expressão durante os séculos XVIII e XIX. Algumas delas também foram consideradas patrimônios da humanidade pela Organização das Nações Unidas para a Educação, a Ciência e a Cultura (UNESCO). Objetivo: Discutir o diagnóstico diferencial histórico da doença de Aleijadinho por meio de uma revisão narrativa da literatura. Métodos: Artigos científicos e livros foram pesquisados em bases de dados como Google Scholar, PubMed e Literatura Latino-Americana e do Caribe em Ciências da Saúde (Lilacs) utilizando como termo principal “Aleijadinho". Posteriormente, foram coletados dados em artigos e livros sobre as possíveis doenças do escultor. Resultados: Desde o primeiro relato da clínica do escultor, vários historiadores e médicos tentaram estabelecer um diagnóstico e várias hipóteses foram sugeridas, como: sífilis, bouba (framboesia trópica), artrite reumatoide, hanseníase (lepra), tromboangeíte obliterante (doença de Buerger), zamparina, cardina, porfiria cutânea tarda, acidente vascular encefálico, amiloidose, trauma e/ou escorbuto. Conclusões: Com base na literatura, os autores concluem que o diagnóstico mais provável da doença de Aleijadinho é compatível com hanseníase.

Palavras-chave: Arte; Diagnóstico; Hanseníase.

\footnotetext{
${ }^{1}$ Centro Universitário de Volta Redonda, Faculdade de Medicina, Volta Redonda RJ, Brazil.

${ }^{2}$ Universidade Federal do Rio de Janeiro, Faculdade de Medicina, Rio de Janeiro RJ, Brazil.

${ }^{3}$ Universidade Federal Fluminense, Faculdade de Medicina, Niterói RJ, Brazil.

RPS (iD https://orcid.org/0000-0003-4838-2813; LSL (D) https://orcid.org/0000-0002-9337-7733; VZZ (DD https://orcid.org/0000-0003-0367-517X; CJC (iD https://orcid.org/0000-0003-0124-0930;MRGF (iD) https://orcid.org/0000-0001-7747-0287

Correspondence: Renato Puccioni Sohler; Email:rpsohler@hotmail.com.

Conflict of interest: There is no conflict of interest to declare.

Authors' contributions: RPS: Designed and conceptualized the report, drafted the manuscript, acquired and analyzed the data; LSL, VZZ: Designed and conceptualized the report, acquired and analyzed the data; CJC: Conceptualized the report, acquired and analyzed the data; MRGF: Designed and conceptualized the report, drafted the manuscript, acquired and analyzed the data, revised the manuscript.

Received on January 22, 2021; Received in its final form on April 04, 2021; Accepted on April 07, 2021.
} 


\section{INTRODUCTION}

Leprosy is an infectious disease prevalent in the tropics, caused by the Mycobacterium leprae, and affecting mainly the skin and peripheral nerves. Its differential diagnosis was extremely difficult in past centuries. One of the persons who may have been affected by this disease was the famous Brazilian Baroque sculptor "Aleijadinho", who suffered from a progressive deformity.

"Aleijadinho" (Antônio Francisco Lisboa) was born on August 29, 1738 in the city of Vila Rica, renamed Ouro Preto, in the state of Minas Gerais State, Brazil. He was the illegitimate son of a talented Portuguese architect, Manoel Francisco Lisboa, and an African slave (Figure 1). He began his education in drawing, sculpture and architecture with his father and continued to develop in a boarding school in 1750 . In 1777, at the age of 39, Antônio Francisco Lisboa fell victim to the disease that deformed him ${ }^{1}$. Thus, he learned how to live with the physical pain that the disease caused, and also with the prejudice and distrust of those who already considered him an inferior human being just because he was a halfbreed. Despite the difficulties, he managed to reinvent himself several times, as his illness progressed, so that over the years the artist had to relearn how to use the instruments ${ }^{1}$. For this reason, the artist's angry and suspicious humor is understandable (he believed that even the compliments

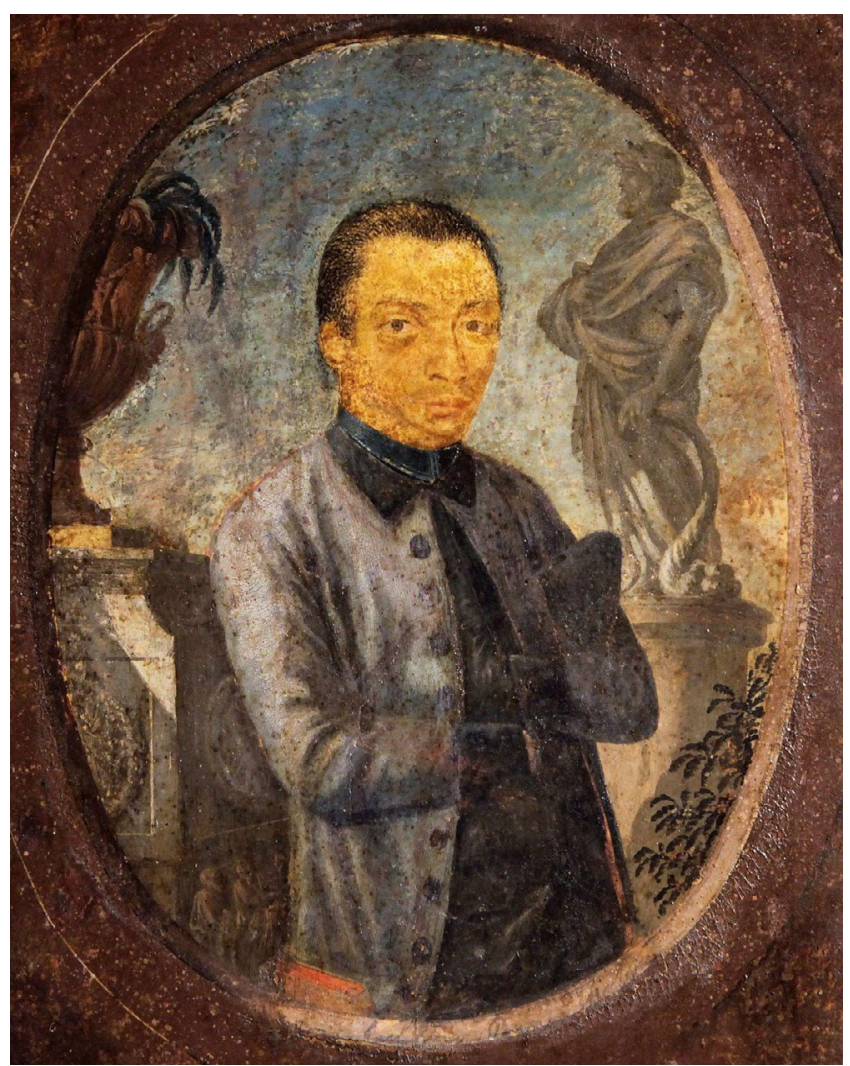

Source: 1800-?, Euclásio Penna Ventura's painting, Congonhas Museum, Congonhas do Campo, Minas Gerais State, Brazil. Public domain.

Figure 1. Painting by Aleijadinho. were mockery). In 1790, Antônio Francisco Lisboa was nicknamed "Aleijadinho", because of his deformities. However, his adversities did not stop him from his passion, art.

Despite his affections, he continued to work with the help of assistants, asking them to tie tools in his fists to work. In 1796-1799, he completed 66 wooden sculptures depicting scenes from the Passion of Christ in the sanctuary of Senhor Bom Jesus de Matosinhos (UNESCO World Heritage Site) in the city of Congonhas do Campo, Minas Gerais, Brazil. Between 1800 and 1805, when the artist was weakened by his illness, he completed the sculptures of the 12 prophets with the help of assistants, which explains the differences in styles and suggests that not all were created by the sculptor himself ${ }^{1}$. These works of art are also in the sanctuary of Senhor Bom Jesus de Matosinhos. Other great works produced by him are the carvings, altarpieces, pulpits and the choir of the church "Nossa Senhora da Conceição" in Jaguará, the sculpture of "Sant’Ana Mestra” (Gold Museum, Sabará) (Figure 2), among countless others. He worked until 1812 and died in 1814.

The scope of the present study was to elucidate the most probable diagnosis of Aleijadinho's disease and discuss other diagnosis suggested in the literature.

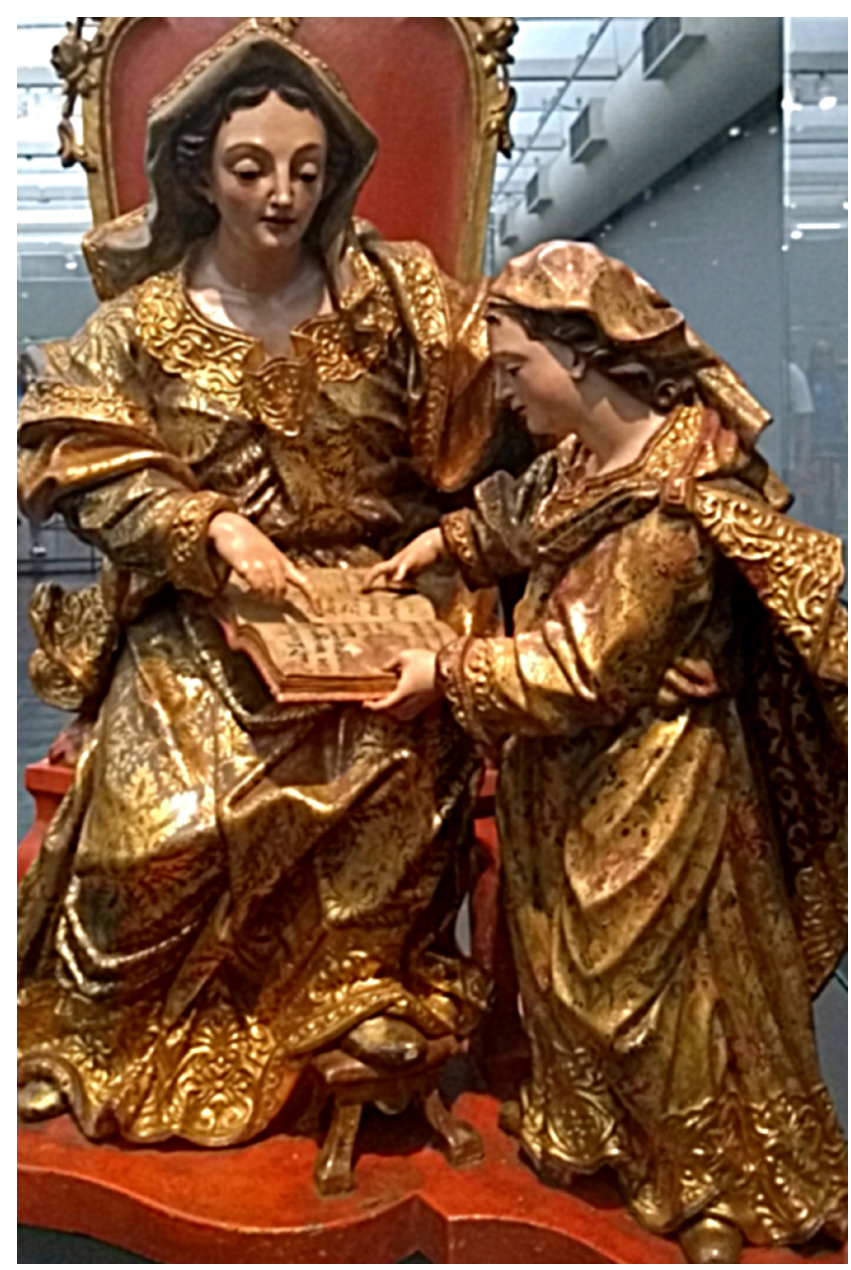

Source: 1778-1779, sculpture by Aleijadinho, Gold Museum, Sabará, Minas Gerais State, Brazil. Public domain.

Figure 2. Sant'Ana Mestra. 


\section{METHODS}

A literature review was performed based on a search in Google Scholar, Lilacs, and Pubmed databases was performed $^{1-7}$. The terms [Aleijadinho AND ilness]; [Aleijadinho AND disease]; [Antônio Francisco Lisboa AND illness]; [Antônio Francisco Lisboa AND disease] were entered as keywords. Subsequent data collection was conducted in books and articles about diseases related to the sculptor ${ }^{8-29}$. The most probable diagnosis was discussed based on the signs and symptoms.

\section{RESULTS}

The initial search using the above keywords found 56 articles, one dissertation, and 26 published books. Of these, 51 articles and 25 books were excluded because the information was repeated or unrelated to Aleijadinho's disease. Finally, we included five articles, one dissertation and one published book. In addition, we used another six books and three articles for the study of the correlated diseases.

\section{The symptoms of the sculptor}

Bretas reported that Aleijadinho had "a gradual loss of movement of the feet and hands. His hand fingers atrophied and bent, and even fell off, leaving only the thumbs and index fingers. He walked on his knees because he had lost all his toes. The sharpness of his choleric humor and the severe pain that he had in his fingers sometimes made him to cut himself with the chisel he was working with. The eyelids became inflamed making the internal part visible. He lost almost all his teeth, his mouth became distorted, and the lower chin and lip drooped. His gaze took on a sinister and ferocious expression that frightened anyone who looked at him." The description indicates ectropion and facial disfigurement with possible peripheral facial paralysis and probable atrophy of the facial nerve, which earned him the nickname "Aleijadinho" in the early 1790s.

According to Bretas, his diagnosis was of morbus gallicus (syphilis) and scurvy. However, in Minas Gerais (his region), scurvy was used for someone with vitiligo, a skin condition with central achromia and peripheral hyperchromia that has a differential diagnosis with tuberculoid leprosy. Aleijadinho worked only at night/dawn to avoid the possible censure of others or not to expose himself to the sun, preventing his disease from worsening ${ }^{1,6}$. According to Bretas (1896), the artist always wore clothes that covered the whole body, showing only the face, perhaps to hide skin lesions, as there were many discriminations at that time, especially in the case of lepromatous leprosy, which would cause the social exclusion of the individual ${ }^{7}$. Regarding life habits, Bretas states that the sculptor had plenty of food, committed venereal excesses, and exaggerated in the consumption of alcoholic beverages. At the end of his life, he was almost immobile and blind, according to his account ${ }^{1}$.

The suspicion of porphyria arose after reddish-colored bones were found during the exhumation of the sculptor's grave. However, there were several bones in the same grave, which made confirmation impossible ${ }^{4}$.

According to Marques Filho, another hypothesis was trauma due to a work accident after a fall that would leave sequelae in the upper and lower limbs.

The progressive and debilitating clinical presentation of Aleijadinho resembles a neurodegenerative disease. On this basis, we evaluate the conditions suggested in the six articles in this review.

Table 1 shows the proposed diagnostic hypotheses for Aleijadinho's disease and compares the arguments for or against the diagnoses.

\section{DISCUSSION}

\section{The historical differential diagnosis of Aleijadinho's disease}

The still speculated diagnoses for Aleijadinho's disease are syphilis $^{1-3}$, yaws ( frambesia tropica) ${ }^{3}$, rheumatoid arthritis $^{2,4}$, Hansen's disease (leprosy) $)^{2,4}$, thromboangiitis obliterans (Buerger Disease) (3,4 $^{3,4}$ zamparina (a disease that appeared in Rio de Janeiro, Brazil, in 1780) ${ }^{3}$, cardina (hallucinogen derived from Carduus benedictus) $)^{1,5}$, porphyria cutanea $\operatorname{tarda}^{2,4,6}$, stroke $^{4}$, amyloidosis ${ }^{4}$, trauma ${ }^{4-6}$ and/or scurvy ${ }^{1,2,3}$.

\section{Yaws}

Yaws ( framboesia tropica) was one of the most prevalent infectious diseases in the tropics (including colonial Brazil) caused by $T$. pallidum subesp. pertenue. It starts with a single lesion with progression to multiple skin lesions. The initial papule becomes papillomatous lesion ("raspberry-like") within weeks, and without treatment, the lesion tends to ulcerate. If painful papillomatous lesions are present on the soles of the feet, it may cause a crablike gait ("crab yaws"). Periostitis with polydactylism and bone pain is also common. Late yaws is manifested by gummas, osteitis, and periostitis $^{8}$. Therefore, it does not resemble Aleijadinho's clinical case, as there is no paralysis, the gait is different from that of Aleijadinho (he walked on his knees), and it is a prevalent childhood infection, not matching the age of the diagnosis $(39 \text { years old })^{8}$.

\section{Syphilis}

Syphilis is a sexually transmitted disease prevalent since colonial Brazil and is initially manifested by a single lesion, the chancre. Within months, it evolves to its secondary form with the appearance of nonpruritic pink or pale read macules that progresses to papule lesions on the entire body. The tertiary form occurs years after the infection and manifests itself 
Table 1. Possible diagnosis of Aleijadinho's disease and arguments for and against each diagnosis.

\begin{tabular}{|c|c|c|}
\hline Disease & Arguments for & Arguments against \\
\hline Yaws & Infection prevalent in colonial Brazil, osteitis and periostitis & $\begin{array}{l}\text { Typical of childhood, there is no paresis, crablike } \\
\text { gait, not similar to Aleijadinho's condition }\end{array}$ \\
\hline Syphilis & Sexually transmitted, high prevalence & $\begin{array}{l}\text { Tabetic gait, Charcot's joints usually } \\
\text { monoarticular, dementia, hemiparesis }\end{array}$ \\
\hline Cardina + trauma & Ulnar nerve injury & $\begin{array}{l}\text { Knee dislocation, injury is not progressive, } \\
\text { without facial nerve palsy }\end{array}$ \\
\hline $\begin{array}{l}\text { Rheumatoid } \\
\text { arthritis }\end{array}$ & $\begin{array}{l}\text { Insidious and additive evolution, chronic synovitis with } \\
\text { peripheral symmetric polyarthritis with deformities, } \\
\text { peripheral ischemia and rheumatoid vasculitis necrosis }\end{array}$ & $\begin{array}{l}\text { There is no facial paralysis, without extra-articular } \\
\text { manifestations, pain due to synovitis making it } \\
\text { impossible to handle instruments, arthritis in } \\
\text { knees making it impossible to walk on knees }\end{array}$ \\
\hline Zamparina & Neurotropic "flu" with a predilection for the locomotor system & $\begin{array}{l}\text { Different periods between the outbreak and } \\
\text { the artist's visit to Rio de Janeiro, acute illness } \\
\text { without necrosis and deformities }\end{array}$ \\
\hline Scurvy & $\begin{array}{l}\text { Polyarticular edema with deformities (later), susceptibility to } \\
\text { infections (generating gangrene and loss of limbs) }\end{array}$ & $\begin{array}{c}\text { Prevalent in sailors, does not correspond to } \\
\text { Aleijadinho's clinical condition. Hemorrhages, } \\
\text { fatigue and asthenia are not compatible with the } \\
\text { artist's lifestyle }\end{array}$ \\
\hline $\begin{array}{l}\text { Thromboangiitis } \\
\text { obliterans }\end{array}$ & Ischemia with loss of limbs & $\begin{array}{c}\text { Does not affect the face, does not explain walking } \\
\text { on knees }\end{array}$ \\
\hline Amyloidosis & Peripheral sensorimotor neuropathy (rare) & $\begin{array}{l}\text { Rapidly progressive, affects kidneys, liver and } \\
\text { heart with low survival rate }\end{array}$ \\
\hline $\begin{array}{l}\text { Porphyria cutanea } \\
\text { tarda }\end{array}$ & $\begin{array}{l}\text { Cutaneous photosensitivity (explains his nocturnal habits), } \\
\text { alcohol is a risk factor }\end{array}$ & $\begin{array}{l}\text { No neurological manifestations, chronic liver } \\
\text { disease, low survival rate }\end{array}$ \\
\hline Leprosy & $\begin{array}{l}\text { Infection with slow, chronic and systemic evolution, paralysis } \\
\text { of the ulnar nerve (claw hand), images of Christ made by } \\
\text { Aleijadinho with a claw hand, carpal tunnel syndrome, } \\
\text { posterior tibial nerve-trunk injury and paresis of the fibular } \\
\text { nerve with difficulty in locomotion, osteoarthritis with plantar } \\
\text { ulcers, blindness, facial paralysis, ectropion }\end{array}$ & \\
\hline
\end{tabular}

with neurological and vascular disorders, including strokes, parenchymal changes, aortitis, aortic aneurysms, meningitis, tabes dorsalis, and others. The major signs and symptoms of tertiary syphilis are chest pain with poor survival rate, headache, hemiparesis or paraparesis, mental confusion, progressive general paralysis, urinary incontinence, proprioceptive ataxia, Charcot's joint, dementia, seizures, and tremors ${ }^{9-11}$. The tabetic gait does not correspond to that of Aleijadinho, as he did not have a wide based gait, placing his legs and feet wide apart and contracting the extensor muscles of his feet as he sways (la danse des tendons). The Charcot's joint can cause degeneration, but it is usually monoarticular and predominantly affects the knee. For these reasons, syphilis does not seem to be the most probable diagnosis. It is possible that the patient had the disease due to its high incidence at the time, but it did not evolve to its tertiary form ${ }^{9-11}$.

\section{Cardina}

The hypothesis of Cardina use (hallucinogen that allows increased sensitivity and inspiration) is associated with a possible fall from a ladder or scaffolding in 1777 during work, which injured Aleijadinhos hands and impaired his gait. In this case, there would be injury to the ulnar nerve. It is also suggested that there was a knee dislocation ${ }^{5}$. However, the history of the genius shows a progressive injury and the suggested hypothesis does not explain the facial nerve paralysis and his way of walking on his knees.

\section{Rheumatoid arthritis}

Rheumatoid arthritis is a rheumatologic disease with an insidious and additive development, affecting several joints. It is a chronic synovitis with symmetrical peripheral polyarthritis. It may be associated with pericarditis, skin nodules, Sjögren's syndrome, renal failure, and vasculitis. In rare cases, peripheral nerves are affected, but there is no facial paralysis ${ }^{12,13}$. It has been suggested that "Aleijadinho" may have had rheumatoid vasculitis, which would cause peripheral ischemia and limb necrosis, and the development of the disease can also cause deformities ${ }^{12,13}$. However, the disease does not have extra-articular manifestations and neuropathy is very rare (mainly facial nerve involvement). Another factor against this hypothesis is the pain caused by synovitis, which would make the handling of instruments extremely painful. In addition, the knees are often affected by arthritis, which would make it impossible for the sculptor to walk on his knees because of pain. Therefore, if this 
were the diagnosis, there would have to be an accompanying disease.

\section{Zamparina}

It is an infectious disease with an outbreak in 1780 in the city of Rio de Janeiro, Brazil. It was documented as a neurotropic "flu" that affected the locomotor system and an encephalopathy that evolved with systemic paralysis ${ }^{5}$. Against this diagnosis is the fact that the sculptor visited Rio de Janeiro only in 1777 , in the same period of his diagnosis, making this infection impossible ${ }^{5}$. Regarding symptoms, zamparina was an acute disease with diarrhea, did not affect limbs, and evolved with parkinsonism and paralysis after encephalitis ${ }^{5}$. Thus, this diagnosis does not seem probable.

\section{Scurvy}

This is a vitamin $\mathrm{C}$ hypovitaminosis that mainly affected sailors, who did not eat food containing this nutrient for months, causing bleeding. In favor of this diagnosis for Aleijadinho is a tendency to infections (justifying gangrene and loss of limbs) and polyarthritis, which causes deformities $^{14,15}$. It should also be noted that the sculptor had no documented hemorrhages, fatigue, or asthenia, and epidemiology does not favor this diagnosis nor does his eating habits. Thus, this hypothesis should not be considered.

\section{Thromboangiitis obliterans (Buerger disease)}

It is a vascular condition prevalent in smokers with ischemic events that can cause the loss of limbs ${ }^{16,17}$. However, the disease does not affect the face and does not explain Aleijadinho's gait, unless he had lost most of his foot. The gait of Aleijadinho is better classified as a neurotrophic degeneration, rather that vascular.

\section{Amyloidosis}

This is usually a rapidly progressive disease that affects multiple systems such as the kidneys, heart, and liver. In favor of this hypothesis is that this disease can cause peripheral sensorimotor neuropathy ${ }^{18,19}$. However, according to Borba Neto et al. ${ }^{18}$ and Seldin et al. ${ }^{19}$, the affected individual initially presents fatigue, which does not fit Aleijadinho's lifestyle and works. Due to the severe visceral involvement, the patient would not live for so many years after his initial manifestation (diagnosis in 1777 (39 years old) and death in 1814 (76 years old)), and he would not be able to have a productive life until the end.

\section{Porphyria cutanea tarda}

PCT is a metabolic disorder in which there is an enzyme deficiency for heme group biosynthesis. PCT occurs sporadically or through family inheritance and is manifested by cutaneous photosensitivity with formation of vesicles. The rupture of vesicles generates areas of atrophy and scarring $^{20}$. This would explain the scars, the covering of the body, and going out at night. According to Desnick and Balwani ${ }^{20}$, alcohol is a risk factor, which fits Aleijadinho's habits. Nevertheless, according to this author, there are no neurological manifestations in this disease and patients with PCT have chronic liver disease, which does not corroborate the loss of strength in extremities, nor Aleijadinho's lifespan, considering his diagnosis at 39 years of age.

\section{Hansen's disease or leprosy}

It is a slow, chronic, and systemic infectious disease with high incidence in Brazil. According to the World Health Organization $^{21}$, there were 28,660 new cases of leprosy in Brazil in 2018, making Brazil the second country with the most new cases in the world. This series was similar at the time of Aleijadinho, being considered endemic in colonial Brazil. The disease can manifest itself in different ways, like the indeterminate form, the tuberculoid leprosy, the lepromatous leprosy, and the borderline form. There is also the pure neural form of leprosy in which there is no skin lesion. It presents as mononeuritis, multiplex mononeuritis, or distal symmetric polyneuropathy. Mononeuropathy is characterized by involvement of a nerve root (a peripheral nerve), while multiple mononeuropathy affects more than one nerve. Polyneuropathy is a disorder of several peripheral nerves and contributes to plantar ulceration due to pain and temperature loss in the feet ${ }^{22}$.

The neurological leprosy presents as enlargement of the nerves and alteration of autonomic, sensory, and motor functions. This enlargement can cause pain on palpation. There is a predominance of the ulnar nerve paralysis, which causes the claw-hand deformity ${ }^{23-25}$. This corresponds to the hyperextension of the fourth and fifth fingers at the metacarpophalangeal joints and flexion at the interphalangeal joints ${ }^{26}$.

This disability makes it extremely difficult to grasp objects, especially cylindrical objects, such as the tools used by Aleijadinho. Another characteristic is the inability to adequately extend the most distal joints, leading the patient to use the fingertips to grasp rather than the volar plate of the phalanx that has the function of resisting trauma. Due to the loss of sensation, the constant use of the hands can result in skin sores, which with time can lead to infection, necrosis and $\operatorname{loss}^{26}$.

The 66 cedar sculptures in the steps of the Via Crucis in the sanctuary of Senhor Bom Jesus de Matosinhos (Congonhas do Campo, Minas Gerais State, Brazil) suggest leprosy, as the hands of Christ have the appearance of ulnar claw hand deformity, while the hands of the other figures do not have this characteristic (as shown in Figure 3). It is also important to note that the artist, tormented by pain and humiliation, was responsible for depicting the agony and suffering of Christ, which supports the hypothesis that Aleijadinho placed the image of one of his hands on Christ.

Leprosy can also affect the median nerve. ${ }^{23,24,25}$ Median paralysis can cause thenar muscles atrophy and weakness, with 


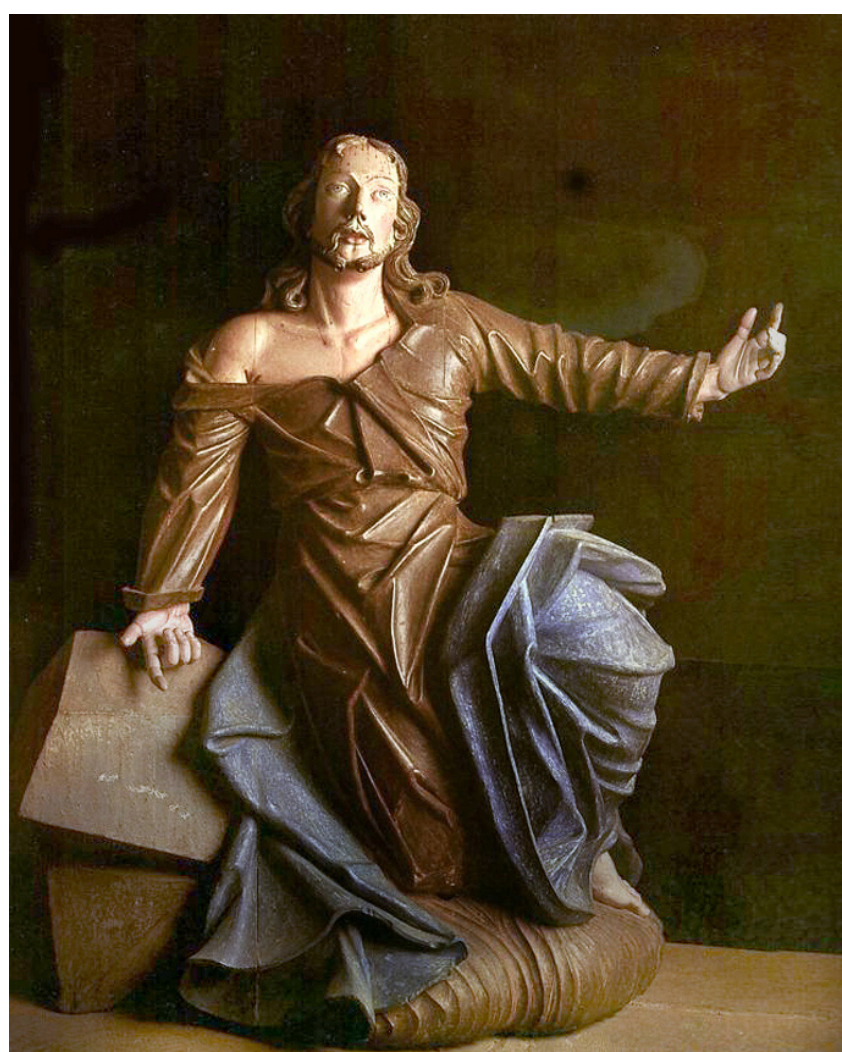

Source: 1796-1799, sculpture by Aleijadinho, Sanctuary of Bom Jesus de Matosinhos, Congonhas do Campo, Minas Gerais State. Public domain.

Figure 3. Monte das Oliveiras, Cristo no Jardim das Oliveiras.

sensory deficit. It can also be associated with carpal tunnel syndrome with pain, paresthesia, and reduced hand mobility ${ }^{27}$.

In the lower limbs, leprosy can act by damaging the trunk of the posterior tibial nerve, which causes loss of plantar flexion and an important loss of sensation in the plantar region with serious secondary consequences (plantar ulcers). Another nerve that may be affected is the common peroneal nerve, which can lead to paralysis of the dorsiflexor and evertor muscles of the foot. The result of this is the foot-drop, a weakness of dorsiflexion of the foot, which severely affects normal gait dynamics ${ }^{23-25}$. The involvement of the nerves can explain the difficulty of the sculptor to walk and maintain the orthostatic position.
Regarding skin lesions, leprosy (tuberculoid) can cause hypochromic macules, with altered sensitivity. Lesions are few and can be located on any skin area ${ }^{23-25}$. This finding makes a differential diagnosis with vitiligo, which would explain the term scurvy (present in Aleijadinho's historical diagnosis). However, no skin lesions were reported in the sculptor's history.

Leprosy can also cause blindness over time, a fact found in the sculptor's history. The bacillus can also injure the VII and V cranial nerves, which explains the existence of ectropion, since injury to the VII cranial nerve leads to lower eyelid atony ${ }^{22,28}$. The involvement of this nerve also generates facial paralysis, which is consistent with Bretas' (1896) description of the artist.

Aleijadinho's clinical condition indicates a possible multiplex mononeuropathy due to the involvement of the median ulnar nerve and impairment of peripheral nerves of the lower limbs, which would lead to plantar ulceration and, thus, infections, loss of limbs, and inability to perform certain movements.

In conclusion, based on this review, the most probable diagnosis for Aleijadinho's disease is leprosy. The symptoms of the case demonstrates that a progressive neuropathy was present, and numerous other traits indicate leprosy. Currently, the definitive diagnosis cannot be established, as it needs one of the following three characteristics: acidfast bacilli on slit-skin smear, hypopigmented or reddish skin patches with permanent loss of sensation, thickening of nerves in peripheral regions with changes in sensitivity and/or strength ${ }^{23-25,29}$.

It is worth mentioning the willpower of the genius who, despite such adversity, conquered the world with his works of art and survived until the age of 76 . He should be considered an example of resilience, creativity, and passion for his profession.

\section{ACKNOWLEDGEMENTS}

The authors gratefully acknowledge the technical assistance provided by Marzia Puccioni Sohler and Laura Maria Zanotti Zatta. In memoriam of Zelia Nunes, sculptor and the first woman to be awarded a gold medal by the Salão Nacional de Belas Artes, Brazil.

\section{References}

1. Bretas RJF. O Aleijadinho. Rev Arq Públ Min. 1896;1(1):161-74.

2. Azevedo VF. Could Aleijadinho have suffered from scleroderma?. Reumatismo. 2008;60(3):230-3. https://doi.org/10.4081/ reumatismo. 2008.230

3. López JE, Torres MM, Salazar JEL, Salazar YL, Fasanella H. Barroco V.- Luso-Brasilero. Arquitectura y escultura. Antonio Francisco Lisboa (El Aleijadinho). Gac Méd Caracas. 2007 Jul;115(3):233-65.

4. Aleixo LM. Aleijadinho: o gênio do barroco mineiro e sua enfermidade. Rev Min Saúde Pública. 2004 Jul-Dec;3(5):61-8.
5. Gama GG. As doenças do Aleijadinho: uma nova interpretação. Acad Min Med. 1998 [accessed on May 29, 2020]. Available at: http://www. acadmedmg.org.br/trabalho/as-doencas-do-aleijadinho-uma-novainterpretacao-geraldo-guimaraes-da-gama-1998/

6. Marques Filho J. A misteriosa doença de Aleijadinho. Rev Ser Médico CREMESP. 2010 Jul-Sep;52:30.

7. Curi LM. Excluir, isolar e conviver: um estudo sobre a lepra e a hanseníase no Brasil [doctorate degree]. Belo Horizonte: Universidade Federal de Minas Gerais; 2010 [accessed on May 29, 2020]. Available at: http://hdl.handle.net/1843/VGRO-8D8P6P 
Lukehart SA. Endemic treponematoses. In: Kasper DL, Hauser SL, Jameson JL, Fauci AS, Longo DL, Loscalzo J, editors. Harrison's principles of internal medicine. 19th ed. New York: McGraw-Hill; 2015. p. 1140.

9. Lukehart SA. Syphilis. In: Kasper DL, Hauser SL, Jameson JL, Fauci AS, Longo DL, Loscalzo J, editors. Harrison's principles of internal medicine. 19th ed. New York: McGraw-Hill; 2015. p. 1132-9.

10. Mattos RA. Sífilis. In: Lopes AC, editor. Tratado de clínica médica. 3rd ed. Rio de Janeiro: Rocca; 2016. p. 3800-7.

11. Talhari CC, Azulay MM, Talhari S, Azulay DR. Treponematoses. In: Azulay RD, editor. Dermatologia. 7th ed. Rio de Janeiro: Guanabara Koogan; 2017. p. 456-73.

12. Laurindo IMM. Artrite reumatoide. In: Lopes AC, editor. Tratado de Clínica Médica. 3rd ed. Rio de Janeiro: Rocca; 2016. p. 1007-21.

13. Shah A, Clair EWS. Rheumatoid arthritis. In: Kasper DL, Hauser SL, Jameson JL, Fauci AS, Longo DL, Loscalzo J, editors. Harrison's principles of internal medicine. 19th ed. New York: McGraw-Hill; 2015. p. 2136-48.

14. Virgílio Nascimento ACK. Distúrbios dos vasos e das plaquetas. In: Lopes AC, editor. Tratado de clínica médica. 3rd ed. Rio de Janeiro: Rocca; 2016. p. 1427-34.

15. Russell RM, Sutter PM. Vitamin and trace mineral deficiency and excess. In: Kasper DL, Hauser SL, Jameson JL, Fauci AS, Longo DL, Loscalzo J, editors. Harrison's principles of internal medicine. 19th ed. New York: McGraw-Hill; 2015. p. 459.

16. Creager MA, Loscalzo J. Arterial diseases of the extremities. In: Kasper DL, Hauser SL, Jameson JL, Fauci AS, Longo DL, Loscalzo J, editors. Harrison's principles of internal medicine. 19th ed. New York: McGraw-Hill; 2015. p. 1643-9.

17. Gauditano G, Yoshinari NH. Doenças reumatológicas com alterações diversas. In: Lopes AC, editor. Tratado de clínica médica. 3rd ed. Rio de Janeiro: Rocca; 2016. p. 1178-200.

18. Borba Neto EF, Yoshinari NH. Amiloidose. In: Lopes AC, editor. Tratado de clínica médica. 3th ed. Rio de Janeiro: Rocca; 2016. p. 1106-8.
19. Seldin DC, Berk JL. Amyloidosis. In: Kasper DL, Hauser SL, Jameson JL, Fauci AS, Longo DL, Loscalzo J, editors. Harrison's principles of internal medicine. 19th ed. New York: McGraw-Hill; 2015. p. 719-23.

20. Desnick RJ, Balwani M. The porphyrias. In: Kasper DL, Hauser SL, Jameson JL, Fauci AS, Longo DL, Loscalzo J, editors. Harrison's principles of internal medicine. 19th ed. New York: McGraw-Hill, 2015. p. 2521-32.

21. World Health Organization. Leprosy - Number of new leprosy cases Data by country, Global Health Observatory Data. 2019 [accessed on Jul 20, 2020]. Available at: https://apps.who.int/gho/data/node.main. A1639?lang=en

22. Freitas MRG, Orsini M. Hanseníase. In: Gagliardi RJ, Takayanagui OM, editors. Tratado de neurologia da Academia Brasileira de Neurologia. 2nd ed. Rio de Janeiro: Elsevier; 2019. p. 766-72.

23. Avelleira JC, Abulafia LA, Azulay DR, Azulay RD. Hanseníase. In: Azulay RD, editor. Dermatologia. 7th ed. Rio de Janeiro: Guanabara Koogan; 2017. p. 426-44.

24. Calux MJF, Pires MC. Hanseníase e micobacterioses em dermatologia. In: Lopes AC, editor. Tratado de clínica médica. 3rd ed. Rio de Janeiro: Rocca; 2016. p. 3790-800.

25. Gelber RH. Leprosy. In: Kasper DL, Hauser SL, Jameson JL, Fauci AS, Longo DL, Loscalzo J, editors. Harrison's principles of internal medicine. 19th ed. New York: McGraw-Hill; 2015. p. 1122-7.

26. Duerksen F, Virmond MCL. Fisiopatologia da mão em hanseniase. In: Duerksen F, Virmond MCL, editors. Cirurgia Reparadora e Reabilitação em Hanseníase, Greenville: ALM International Inc.; 1997. p. 199-209.

27. Campbell WW. Peripheral neuroanathomy and focal neuropathies. In: Campbell WW, editor. DeJong's the neurologic examination. 7th ed. Philadelphia: Wolters Kluwer; 2013. p. 517-34

28. Herzog Neto G. Afecções das pálpebras. In: Dantas AM, editor. Essencial em oftalmologia. Rio de Janeiro: Guanabara Koogan; 2011. p. 245-324.

29. World Health Organization. Guidelines for the diagnosis, treatment and prevention of leprosy. New Delhi: World Health Organization, Regional Office for South-East Asia; 2017. 